\title{
CORRECTIONS
}

\section{Doctors call for better management of suspected measles cases}

In the first sentence of the third paragraph of this News story by Jacqui Wise on bmj.com (BMJ 2013;346:f1127, doi:10.1136/ bmj.f1 127), the details of a $B M J$ reference are missing. It is a

Rapid Response ("Why is measles so difficult") by Kenneth
Lamden and colleagues and can be found at www.bmj.com/ content/346/bmj.f245/rr/631249.

Cite this as: BMJ 2013;346:f1366

๑ BMJ Publishing Group Ltd 2013 